\title{
EVALUATION OF SUBSTRATE LIMITATION KINETICS IN HETEROTROPHIC MICROALGAL CULTURES
}

\author{
M. M. MARONEZE ${ }^{1}$, G. J. G. TEIXEIRA ${ }^{1}$, C. NEVES ${ }^{1}$, L. Q. ZEPKA ${ }^{1}$, M. I. QUEIROZ², \\ E. JACOB-LOPES ${ }^{1}$
}

${ }^{1}$ Universidade Federal de Santa Maria, Departamento de Ciência e Tecnologia dos Alimentos

${ }^{2}$ Universidade Federal de Rio Grande, Escola de Engenharia de Alimentos

E-mail para contato: jacoblopes@pq.cnpq.br

\begin{abstract}
RESUMO - The aim of this research was to evaluate the kinetic modeling of the substrate (chemical oxygen demand) limitation in heterotrophic microalgal cultures. The experiments were carried out in a bubble column bioreactor in batch mode at $30^{\circ} \mathrm{C}, \mathrm{pH} 8.0$, absence of light, $1 \mathrm{VVM}$ and $\mathrm{C} / \mathrm{N}$ ratio of 50 . The limitation for chemical oxygen demand was investigated through of four models (Monod, Teissier, Moser, Contois). The Moser model was found to be sufficient to describe the substrate (COD) limitation, as evidenced by the statistical criteria. The predictions indicate maximum specific growth rate of $0.055 \mathrm{~h}^{-1}$ and a saturation constant of $86.25 \mathrm{mgCOD} . \mathrm{L}^{-1}$.
\end{abstract}

\section{INTRODUCTION}

Fish processing is an important world economic activity. This process involves significant water consumption, on average equal to $11 \mathrm{~m} 3$.tonne1 of fish processed, resulting in a significant volume of wastewater. These agro-industrial wastes have a high concentration of organic matter and are a suitable environment that favors microalgae heterotrophic cultivation. Where nitrogen $(\mathrm{N})$ and phosphorus $(\mathrm{P})$ are usually found in favorable carbon/nitrogen $(\mathrm{C} / \mathrm{N})$ and nitrogen/phosphorous $(\mathrm{N} / \mathrm{P})$ ratios that support microalgal growth (Queiroz et al., 2013).

The use of cyanobacteria for wastewater treatment was suggested years ago (Caldwell, 1946; Oswald and Gotaas, 1957). Microalgal heterotrophic bioreactors may offer an inexpensive alternative to conventional forms of secondary and tertiary wastewater treatment, such as, activated sludge, nitrification-denitrification and chemical phosphorus precipitation. Moreover, simultaneously is generated a biomass that has potential for the production of single-cell protein and single-cell oil that can be used as feedstock in the animal feed and bioenergy industry (Queiroz et al., 2007).

The first step in promoting an efficient biomass production and wastewater treatment system is the optimization of culture medium conditions. This can be done by testing different points in the treatment, different dilution conditions, and nutrient supplementation (Joseph and Joseph, 2001). Experiment is a good method to investigate the technology. But it will take a long period of time and a lot of funds to do experiment. In this sense, mathematical modeling has been widely utilized in science and engineering in order to improve understanding of the behavior of systems, explore new theoretical concepts, predict system performance and, in an increasing number of cases, aid in the solution of practical design problems (Zhou et al., 2014). 
In heterotrophic cultures of microalgae, carbon is a limiting nutrient, since it is the main energy source of the microorganism. In this sense, the objective of this research was to evaluate the kinetic modeling of the substrate (chemical oxygen demand) limitation in heterotrophic microalgal cultures.

\section{MATERIAL AND METHODS}

\subsection{Microorganism and culture conditions}

Axenic cultures of Aphanothece microscopica Nägeli (RSMan92) were originally isolated from the Patos Lagoon estuary, from the state of Rio Grande do Sul, Brazil $\left(32^{\circ} 01^{\prime} \mathrm{S}\right.$ - 52 $\left.{ }^{\circ} 05^{\prime} \mathrm{W}\right)$. Stock cultures were propagated and maintained in synthetic BG11 medium (Braun-Grunow medium) (Ripka et al., 1979). The incubation conditions used were $30^{\circ} \mathrm{C}$, photon flux density of $30 \mu \mathrm{mol} \cdot \mathrm{m}^{-2} \cdot \mathrm{s}^{-1}$, and a photoperiod of $12 \mathrm{~h}$.

\subsection{Wastewater}

Fish processing wastewater was utilized in the experiments as culture medium. The wastewater was obtained from the fish processing industry (Rio Grande, RS, Brazil). The wastewater was collected from the discharge point of the equalization tank for 12 months from January to December of 2007.

\subsection{Bioreactor design}

Measurements were made in a bubble column photobioreactor. The system was built with $4 \mathrm{~mm}$ thick, had an internal diameter of $10 \mathrm{~cm}$, a height of $100 \mathrm{~cm}$, and a nominal working volume of $4.5 \mathrm{~L}$. The dispersion system for the reactor consisted of a $1.5 \mathrm{~cm}$ diameter air diffuser located in the centre of the column.

\subsection{Obtaining of the kinetic data in experimental bioreactor}

The experiments were carried out in bioreactors operating in a batch mode, fed with 4.5L of fish processing wastewater. The experimental conditions were as follows: initial cell concentration of $0.2 \mathrm{~g} . \mathrm{L}^{-1}, \mathrm{pH}$ adjusted to $7.6, \mathrm{C} / \mathrm{N}$ and $\mathrm{N} / \mathrm{P}$ ratio of 20 and 10, respectively, isothermal reactor operating at temperatures of $30^{\circ} \mathrm{C}$, absence of light, and continuous aeration of $1 \mathrm{VVM}$. The cell concentration was monitored every $6 \mathrm{~h}$ during the microbial growth phases. Residence times of up to $30 \mathrm{~h}$ were considered for all the experiments. The tests were carried out in duplicate and the kinetic data referred to the mean of four repetitions.

\subsection{Kinetic models, mathematical resolution and statistical validation}

Five kinetics models of substrate limitation were used: Monod (1949), Tessier (1936), Moser (1958) and Contois (1959). The equations of models are shown in Table 1.

Newton Method was used to solve the equations in Microsoft Excel XP Software. Initial estimates of the parameters values were required and a good choice of initial values is critical since a poor starting point can result in divergence or a wrong solution. A reasonable initial estimate for the umax and ks coefficient was obtained through the graph $(\ln X)$ vs. (t). 
Least square was used in Microsoft Excel XP Software to solve the models through the minimization of the least value of the square error sums between the empirical and predicted values.

The indices of performance of the models considered were: root mean square error (RMSE), standard error of prediction (\%SEP), Bias factor (Bf) and accuracy factor (Af) (Ross, 1996).

Table 1 - Equation of models

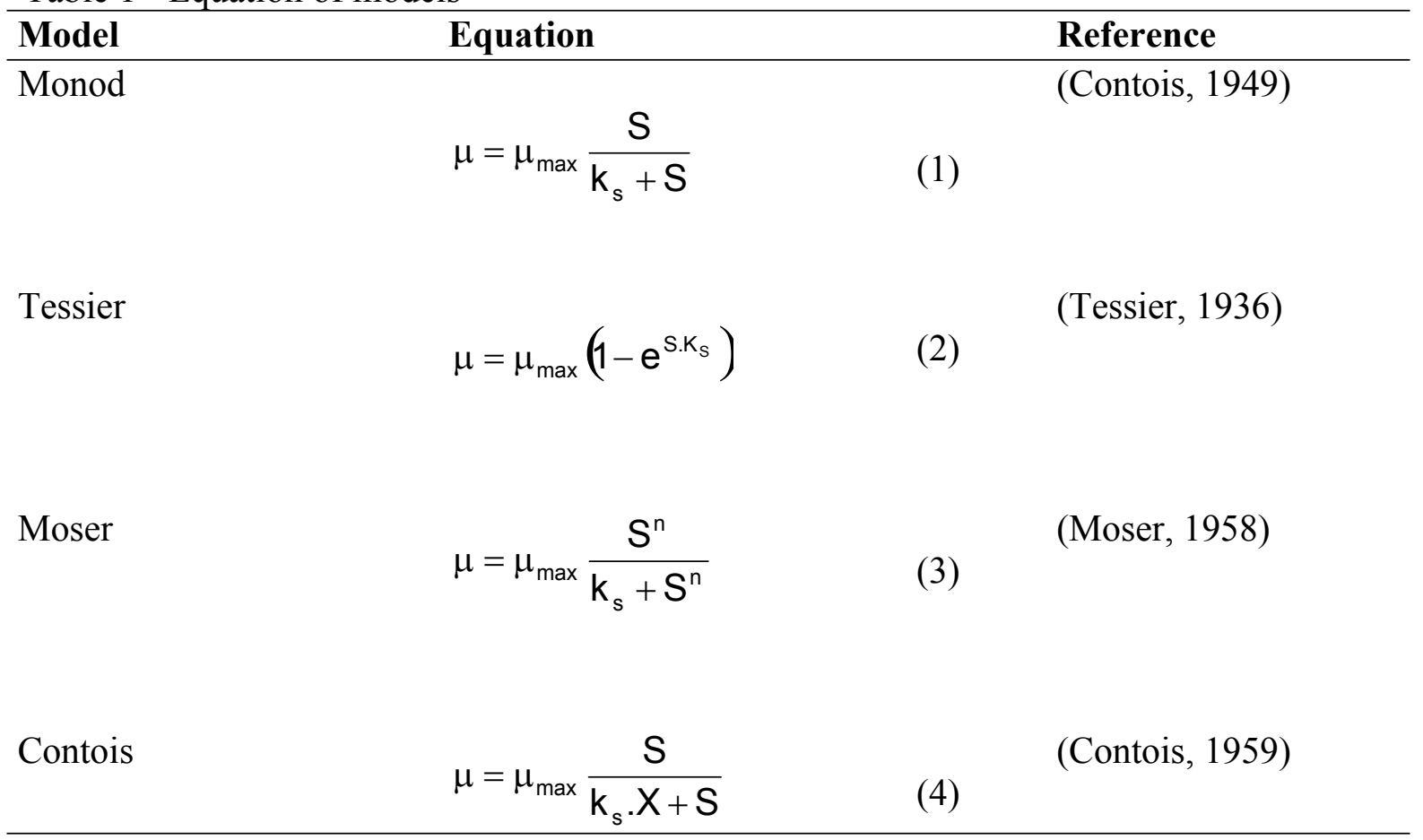

\section{RESULTS AND DISCUTION}

Modeling may be an effective method to help researchers to investigate the process of microalgae growth in bioreactors, which can offer the potential to reduce, or even replace, the need for physical experimentation when exploring new material and/or process options. In this sense, the Table 2 shows the performance indices of the models tested.

Table 2 - Data on statistical model validation

\begin{tabular}{ccccc}
\hline Parameters & Monod & Teissier & Moser & Contois \\
\hline RMSE & 0.0038 & 0.0067 & 0.0031 & 0.0057 \\
Bf & 1.00 & 0.95 & 1.01 & 1.00 \\
Af & 1.13 & 1.22 & 1.10 & 1.17 \\
\%SEP & 12.91 & 23.09 & 10.74 & 19.58 \\
\hline
\end{tabular}

The RMSE provides a measure of the agreement between experimental data and the model. The best model agreement will have a low value of RMSE. The lowest values were 
observed with the Monod and Moser models (0.0038 and 0.0031 , respectively). The bias factor (Bf) gives an objective indication of the best performance of the model. Ross (1996) suggested that perfect agreement between predictions and observations is represented by a $\mathrm{Bf}$ of 1 . Higher or lower values indicate a systematic over or underestimation of the observed values, respectively. Models describing growth rate with $\mathrm{Bf}$ in the range of $0.9-1.05$ can be considered good. In the range of $0.7-0.9$ or $1.06-1.15$, acceptable, and 0.7 or 1.15 , unacceptable. In this parameter, all models showed goods results (0.95 to 1). The accuracy factor represents the difference between the mean observed values and the predicted values. The increase in this factor results in a low capacity for prediction of correctness between the estimated and true values. Again, Monod and Moser models were close to 1 (1.13 and 1.10, respectively). The standard error of prediction (\%SEP) confirms the lower residual of the Moser model.

Based on the statistical validation of the models, the Moser model was chosen for use to evaluation of the process. Thus, Table 3 shows the kinetic parameters obtained from the model Moser.

Table 3 - Kinetics parameters estimated by Moser model

\begin{tabular}{cc}
\hline Parameters & Moser \\
\hline$\mu$ máx $\left(\mathrm{h}^{-1}\right)$ & 0.055 \\
$\mathrm{Ks}$ & 86.25 \\
$\mathrm{~N}$ & 0.727 \\
\hline
\end{tabular}

The specific growth rate, $\mu$, is a measure of how quickly a microbial population is growing. The growth kinetics obtained in this present study show higher maximum specific growth rates $\left(0.05 \mathrm{~h}^{-1}\right)$ those usually reported in others researches. In optimized conditions Queiroz et al. (2011) and Queiroz et al. (2013) for Aphanotece microscopica Nägeli reported values of 0.049 and $0.03 \mathrm{~h}-1$, respectively. The saturation constant value (86.25 mgCOD.L $\mathrm{L}^{-1}$ ) represents the substrate concentration required to achieve $50 \%$ of the maximum growth, it becomes a guideline for adjusting the most efficient substrate concentration in the feed of the continuous and/or feed batch processes (Chen et al., 2001).

\section{CONCLUSIONS}

The Moser model was found to be sufficient to describe the substrate (COD) limitation, as evidenced by the statistical criteria. The predictions indicate maximum specific growth rate of $0.055 \mathrm{~h}^{-1}$ and a saturation constant of $86.25 \mathrm{mgCOD}^{-\mathrm{L}^{-1}}$.

\section{REFERENCES}

CALDWELL, D. H. Sewage oxidation ponds: performance, operation and design. Sewage Works Int., v.18, p.433-458, 1946.

CONTOIS, D. E. Kinetics of bacterial growth: relationship between population density and specific growth rate of continuous culture. J Gen Microbiol., v. 21, p.40-50, 1959.

JOSEPH, V.; JOSEPH, A. Microalgae in petrochemical effluent: growth and biosorption of total dissolved solids. Environ. Contam. Toxicol., v. 66, p.522-527, 2001. 


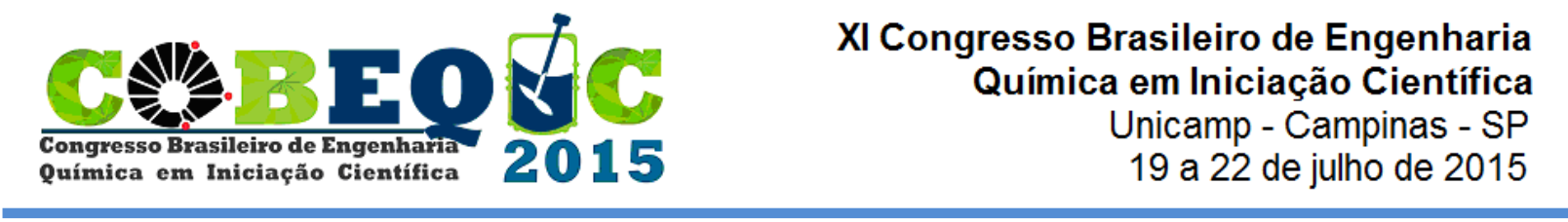
1949.

MONOD, J. The growth of bacterial cultures. Ann. Rev. Microbiol., v.3, p.371-394,

MOSER, H. The dynamics of bacterial populations maintained in the chemostat. The Carnegie institute, Washington, DC, 1958.

OSWALD, W. J.; GOTAAS, H. B. Photosynthesis in sewage treatment. Trans. Am. Soc. Civ. Eng., v.122, p.73-105, 1957.

QUEIROZ, M. I.; HORNES, M.; MANETTI, A. G. S.; ZEPKA, L. Q., JACOBLOPES, E.. Fish processing wastewater as a platform of the microalgal biorefineries. Biosystems Engineering, v.115, p.195-202, 2013.

QUEIROZ, M. I.; JACOB-LOPES, E.; ZEPKA, L. Q.; BASTOS, R.; GOLDBECK, $\mathrm{R}$. The kinetics of the removal of nitrogen and organic matter fromparboiled rice effluent by cyanobacteria in a stirred batch reactor. Bioresource Technol, v.98, p.2163-2169, 2007.

RIPPKA, R. et al. Generic Assignments Strain Histories and Properties of Pure Cultures of cyanobacteria. Journal of General Microbiolog. Great Britain., v.111, p.1-61, 1979.

ROSS T. Indices for performance evaluation of predictive models in food microbiology. J Appl Bacteriol., v.8, p.81-501, 1996.

TEISSIER, G. Le lois quantitatives de la croissance. Ann. Phisiol-Chim. Biol., v.12, p.527-73, 1936.

ZHOU, X., YUAN, S.,CHEN, S.,SONG, B. Modelling microalgae growth in nitrogenlimited continuous culture. Energy, v.73, p.575-580, 2014. 